\title{
The Guest List
}

Margo Natalie Crawford is an Associate Professor of English Literature at Cornell University. She is the author of Dilution Anxiety and the Black Phallus (2008), a study of the body politics of lighter- and darkerskinned blackness, and the co-editor, with Lisa Gail Collins, of New Thoughts on the Black Arts Movement (2006).

David R. Ellison is Distinguished Professor in the Humanities at the University of Miami, Florida. His publications include The Reading of Proust (1984), Understanding Albert Camus (1990), Of Words and the World: Referential Anxiety in Contemporary French Fiction (1993), Ethics and Aesthetics in European Modernist Literature: From the Sublime to the Uncanny (2001) and A Reader's Guide to Proust's In Search of Lost Time (2010).

Alex Goody is Reader in Twentieth-Century Literature at Oxford Brookes University. She is the author of Modernist Articulations: A Cultural Study of Djuna Barnes, Mina Loy and Gertrude Stein (2007) and Technology, Literature and Culture (2011), and the co-editor of American Modernism: Cultural Transactions (2009).

Susan Jones is Fellow and Tutor in English Literature at St Hilda's College, University of Oxford. She has published widely on Joseph Conrad, including Conrad and Women (1999), and is editing Conrad's Chance for the Cambridge Edition of the Works of Joseph Conrad. She has also written articles on modernism and dance and her monograph Literature, Modernism and Dance is forthcoming from Oxford University Press.

Kate McLoughlin is Senior Lecturer in English Literature at Birkbeck, University of London. She is the author of Authoring War: The Literary 
Representation of War from the Iliad to Iraq (2011) and Martha Gellhorn: The War Writer in the Field and in the Text (2007), editor of The Cambridge Companion to War Writing (2009) and co-editor of Memory, Mourning, Landscape: Interdisciplinary Essays (2010) and Tove Jansson Rediscovered (2007).

Margot Norris is Chancellor's Professor Emerita of English and Comparative Literature at the University of California, Irvine. Her publications include Virgin and Veteran Readings of Ulysses (2011), Suspicious Readings of Joyce's Dubliners (2003), Writing War in the Twentieth Century (2000), Joyce's Web (1992), Beasts of the Modern Imagination: Darwin, Nietzsche, Kafka, Ernst and Lawrence (1985) and The Decentered Universe of Finnegans Wake (1976).

Jean-Michel Rabaté is Vartan Gregorian Professor in the Humanities at the University of Pennsylvania and co-founder and curator of Slought Foundation. He is an editor of the Journal of Modern Literature and a fellow of the American Academy of Arts and Sciences. He has authored or edited more than thirty books on modernism, psychoanalysis, art and philosophy. Recent titles include 1913: The Cradle of Modernism (2007), The Ethic of the Lie (2008) and Etant donnés: 1) l'art, 2) le crime (2010).

Bryony Randall is Lecturer in English Literature at the University of Glasgow. She is the author of Modernism, Daily Time and Everyday Life (2007), co-editor of Virginia Woolf in Context (2012) and is coediting Woolf's short fiction for the Cambridge Edition of the Works of Virginia Woolf.

Morag Shiach is Professor of Cultural History and Vice-Principal for Humanities and Social Sciences at Queen Mary, University of London. Her most recent books are Modernism, Labour and Selfhood in British Literature and Culture, 1890-1930 (2004) and, as editor, The Cambridge Companion to the Modernist Novel (2007).

Angela Smith is Emerita Professor of English Literature at the University of Stirling. She is the editor of Katherine Mansfield's Selected Stories for the Oxford World's Classics. Her other publications include East African Writing in English (1989), Katherine Mansfield and Virginia Woolf: A Public of Two (1999) and Katherine Mansfield: A Literary Life (2000). 
viii The Guest List

Nathan Waddell is Advance Research Fellow at the University of Nottingham. He is the author of Modernist Nowheres: Politics and Utopia in Early Modernist Writing, 1900-1920 (2012) and Modern John Buchan: A Critical Introduction (2009). He is co-editor of Wyndham Lewis and the Cultures of Modernity (2011).

Joanne Winning is Senior Lecturer at Birkbeck, University of London. Her publications include The Pilgrimage of Dorothy Richardson (2000) and the edited Bryher: Two Novels (2000). 